\title{
A PAISAGEM SONORA EM VALSA PARA BRUNO STEIN
}

Viviane Aparecida Pandolfo Debortolli ${ }^{1}$ Gérson Luís Werlang²

\begin{abstract}
Resumo: O romance Valsa para Bruno Stein, de Charles Kiefer, narra um curto período da vida do oleiro Bruno, que estando prestes a completar setenta anos, apaixona-se pela nora, com quem convive há anos. O protagonista é apreciador de música, a qual está intrinsicamente presente tanto na realidade diegética quanto na estrutura do enredo e se configura num dos elementos essenciais da paisagem sonora do romance. Diante disso, este estudo se propõe a analisar as particularidades da paisagem sonora na obra, evidenciando como os personagens se relacionam com ela e de que forma ela interfere na progressão da narrativa. As bases teóricas desta análise se dão por meio dos estudos de Murray Schafer (2011), musicólogo que desenvolveu um estudo sobre a paisagem sonora mundial, e Gérson Werlang (2011), que aplicou o conceito aos estudos literários.
\end{abstract}

Palavras- chave: Paisagem Sonora; Música, Literatura.

\section{THE SOUNDSCAPE IN VALSA PARA BRUNO STEIN}

\begin{abstract}
The novel Valsa para Bruno Stein, by the Brazilian writer Charles Kiefer, narrates a short period of the life of a potter named Bruno Stein, who, about to turn seventy years old, falls in love with his daughter-in-law. The protagonist is a connoisseur of music, which is intrinsically present both in the diegetic reality and in the structure of the plot and is one of the essential elements of the soundscape of the novel. Therefore, this study aims to analyze the particularities of the soundscape in the work, showing how the characters relate to it and how it interferes in the progression of the narrative. The theoretical bases of this analysis are given by the studies of Murray Schafer, a musicologist who developed a study on the world soundscape, and Gérson Werlang, who applied the concept to literary studies.
\end{abstract}

Keywords: Soundscape; Music, Literature.

1 Mestranda em Letras (UFSM), E-mail viviane.debortolli@hotmail.com

2 Doutor em Letras pela Universidade Federal de Santa Maria, professor adjunto na UFSM. E-mail: gerwer@rocketmail. com. 


\section{INTRODUÇÃO}

Charles Kiefer é um escritor gaúcho com uma produção que compreende contos, novelas, romances, poemas, ensaios, cuja obra iniciou em 1982 com a novela Caminhando na Chuva, a qual abriu caminho para outras narrativas que transcorrem majoritariamente no que seria o interior do Rio Grande do Sul. Não é diferente com romance Valsa para Bruno Stein, publicado em 1986, que acontece na fictícia cidade de Pau-d'Arco, equivalente à terra natal de Kiefer, Três de Maio (RS). A narrativa se passa em poucos meses e acontece em torno da época do carnaval no ano de 1983, quando, na iminência de completar seu septuagésimo aniversário, Bruno Stein, temente a Deus, religioso, correto, trabalhador, homem relativamente culto, apreciador de bons livros e boas músicas e escultor nas horas vagas, percebe-se apaixonado pela nora após flagrá-la nua no banho. Entremeado pela sonoridade musical, o romance se desenrola até nora e sogro sucumbirem aos desejos sexuais.

Nesse contexto, percebe-se que a sonoridade à qual os personagens estão submetidos tem profunda relevância na história, já que as questões sonoras estão concatenadas aos outros elementos da narrativa. Estruturas diegéticas formadas a partir de elementos musicais e sonoros são bastante antigas, considerando que a "interação entre música e literatura em todas as épocas talvez possa ser explicada pela inexistência de fronteiras na imaginação e pela comunhão de objetivos que unem a arte" (WERLANG, 2011, p. 26), o que é novo, porém, é o estudo da abordagem, principalmente da paisagem sonora, na literatura. Para Debortolli e Werlang (2020),

O estudo da paisagem sonora nas obras literárias é um campo em aberto, com muito a ser explorado devido, especialmente, ao fato de que este tipo de análise é algo recente nos estudos literários. Alguns escritores se utilizam de elementos sonoros e musicais para compor seus textos, de forma que é possível verificar um encadeamento imperativo entre a narrativa e a paisagem sonora (DEBORTOLLI; WERLANG, 2020, p. 256).

O conceito de paisagem sonora surgiu dos estudos de acústica, quando o pesquisador, educador e musicologista Murray Schafer (2011) dedicou-se a pesquisar as peculiaridades dos diferentes sons presentes no mundo, sejam naturais ou produzidos pela ação humana, e definiu que ela pode estar relacionada a "uma composição musical, a um programa de rádio ou mesmo a um ambiente acústico" (SCHAFER, 2011, p. 23). A partir desses estudos, paisagem sonora pode ser entendida como

o conjunto de sonoridades presentes em um determinado local, seja ele um espaço pequeno (um cômodo de casa, uma sala, etc.) ou um espaço amplo (uma cidade, uma floresta, os oceanos). Cada um desses ambientes possui um conjunto de sons que lhes são próprios, partes integrantes de sua constituição (DEBORTOLLI; WERLANG, 2020, p. 257).

Percebendo que a estrutura diegética dos textos literários ficcionais apresentam elementos sonoros, o músico, escritor e doutor em literatura Gérson Werlang transpôs o estudo de Schafer ao campo literário, quando constatou em sua análise, relativa à obra de Erico Verissimo, que lá a

[...] paisagem sonora é de suma importância, e esses sons não são apenas os sons musicais tradicionais, mas também o ruído das ruas, do trânsito, do canto dos pássaros, a festividade transmitida pelos ruídos caseiros, e muitos outros recursos provenientes de um âmbito estritamente sonoro (WERLANG, 2011, 38).

Em Valsa para Bruno Stein a paisagem sonora também é de profunda notoriedade, já que o protagonista está constantemente envolto em questões sônicas, seja pelas músicas que ouve, seja pelo estilo musical com o qual antipatiza (a valsa), seja pelos ruídos da televisão que o incomodam. Em vista disso, urge destacar que "o que o analista da paisagem sonora precisa fazer, em primeiro lugar, é descobrir os seus aspectos significativos, aqueles sons que são importantes por causa de sua 
individualidade, quantidade ou preponderância" (SCHAFER, 2011, p. 23). É a isto que esta pesquisa se propõe: apontar os aspectos significativos da paisagem sonora no objeto de estudo selecionado, o romance Valsa para Bruno Stein.

\section{A ESTRUTURA MUSICAL DO ROMANCE}

Em mais de um momento durante o desenrolar da trama há uma trilha sonora, marcando a presença da música em pontos específicos da narrativa. A própria estrutura da valsa é transposta ao campo diegético, além de ter servido de inspiração para o escritor. Para Kiefer (2002), "durante o processo de criação eu escrevia ouvindo a Valsa Mephisto, de Liszt ${ }^{3}$. Creio, até, que seja essa a valsa que o bêbado, Arno Wolf, toque em seu violino na noite do incêndio" (KIEFER, 2002, p. 41). Essa referência ao incêndio diz respeito ao desfecho da narrativa, quando o protagonista vê sua olaria em chamas e decide deixá-la consumir-se no fogo, assim como ele simbolicamente consumirase no fogo do desejo ao possuir sexualmente a nora minutos antes. Essa decisão acabaria por custar a vida do vizinho bêbado, que se dirigia até a fábrica enquanto assoviava uma valsa para Bruno Stein (diferentemente de como o autor diz, na narrativa a música é assoviada, e não tocada em um violino).

A música não esteve presente apenas enquanto o autor compunha a paisagem musical da produção do romance, mas fez parte das preferências particulares do personagem central. $\mathrm{O}$ estilo musical da valsa enquanto eixo estruturante foi uma decisão consciente do autor:

3 Franz Liszt (1811 - 1886), compositor e pianista húngaro. Com um "intelecto inquieto, foi também incessantemente criativo, buscando a nova música. (...) Maior pianista de sua época, compôs algumas das peças para piano jamais escritas". Compôs a "Sinfonia Fausto, em três movimentos, com seus estudos vívidos dos personagens Fausto, Margarida e Mefistófeles, apoia-se no artifício técnico (sobretudo a transformação temática), mais do que na narrativa musical, para transmitir sua mensagem". A Valsa Mephisto, também baseada no Fausto de Goethe, é uma de suas grandes obras pianísticas (GROVE, 1994, p, 542).
Durante algumas semanas, refleti sobre a forma, sobre a arquitetura. Um dia, o insight iluminou minha mente obscura: a forma do meu romance devia reproduzir a forma da valsa, a sintaxe de seus compassos: um tempo longo e dois breves. Por isso, por muitas de suas camadas de significação, Valsa para Bruno Stein, repete, à exaustão, o compasso trinário da forma musical que lhe dá sustentação (KIEFER, 2002, p. 41. Grifos do autor).

Mais do que um elemento sônico, a música instaura-se definitivamente na estrutura do romance, o qual apresenta essa transfiguração de diferentes maneiras ao longo do texto.

Se se pudesse ver do alto a geografia da olaria, ela se compõe de um núcleo central, a fábrica, e dois outros menores, galpões e forno. No núcleo residencial, há uma casa maior e duas outras menores, a casa antiga e o galpão das esculturas. Em torno de um personagem forte, há sempre outros dois, mais fracos. Bruno-Olga-Valéria; Erandi-Gabriel-Mário; Verônica-Carlos-Luís; Sandra-Eunice-Luísa. A própria estrutura capitular do romance, repete, formalmente, uma valsa: a primeira parte, Figura angelical, tem 124 páginas. A segunda, $A s$ luzes da cidade, tem 42 páginas. E a terceira, $O$ incêndio, tem 22 páginas (KIEFER, 2002, p. 41. Grifos do autor).

Para o autor, o compasso ternário marcado por um tempo forte seguido de dois tempos fracos pode ser metaforizado, ao recriar mentalmente a figura do que seria a estrutura física da propriedade, vista de cima. Um esforço mental imagético torna possível a visualização da planta baixa da olaria.

Tal figura revelaria divisões em núcleos subdivididos em algo grande cercado por outras duas coisas, de ordem semelhante, só que menores. No primeiro bloco descrito por Kiefer há a fábrica em oposição aos galpões e ao forno. Era na fábrica que Bruno e os empregados passavam a maior parte do dia, era de lá que saíam as grandes quantidades de tijolos que posteriormente seriam queimadas no forno. Ou seja, as instalações secundárias não eram só menores em tamanho, como também em importância no decorrer da narrativa. A elas cabia apenas o final do processo. Semelhante é o que ocorre com o bloco residencial, o qual opõe a casa grande, em que todos moram (Bruno, Olga, Carlos, Valéria e as quatro filhas), às outras menores, por onde circula menos gente, onde não há interações sociais entre os familiares, etc.

(DEBORTOLLI; WERLANG, 2019, p. 520). 
Com a finalidade de identificar a transfiguração da valsa no romance no que tange à relação entre os personagens, é possível verificar o que o autor sugere quando diz que dois personagens fracos têm como eixo, em torno do qual giram, um personagem forte. Veja-se o caso de Bruno, Olga e Valéria.

$\mathrm{Na}$ construção ternária forte/fraco/fraco, representada por Bruno/Olga/Valéria, percebe-se que eles estão no mesmo nível no sentido de que juntos formam uma espécie de triângulo amoroso. Dessa forma, uma das semelhanças é que todos são adultos e possuem um relacionamento afetivo que se confunde familiarmente. Todos casaram, construíram família e tiveram experiências advindas dessa condição. No entanto, Bruno é forte por não ser submisso a nada, nem às ideias do filho de modernizar a olaria, por resistir a todas as mudanças que se impõe ao seu redor, por comandar a casa com mãos de ferro, inclusive proibindo as netas de ir aos bailes de carnaval. Olga e Valéria são fracas especialmente por serem submissas à condição social que lhes fora imposta e que aceitaram sem questionar (DEBORTOLLI; WERLANG, 2019, p. 517).

A metáfora da valsa se daria, então, tanto nas relações entre os personagens, na relação entre os componentes da estrutura física da propriedade, na divisão dos capítulos do livro, de forma que o título do romance seria ao mesmo tempo o nome de uma valsa, composta para o personagem, já que o livro soaria mesmo como uma espécie de valsa para Bruno Stein.

\section{A PAISAGEM SONORA EM VALSA PARA BRUNO STEIN}

Nos primeiros parágrafos do romance é apresentado ao leitor o personagem principal, o qual teve uma infância com fortes recordações negativas, já que conviveu por um longo tempo com a violência e brutalidade do pai. A hostilidade do ambiente familiar em que Bruno cresceu divergia da presença da música na vida do menino, introduzida no contexto familiar devido ao apreço que o pai nutria, especialmente por valsa ${ }^{4}$, tocada por ele diariamente em seu violino. Em virtude dos problemas de afetividade com seu progenitor, Bruno tornou-se incapaz de apreciar valsa, embora fosse um profundo apreciador e conhecedor de música. A memória auditiva do protagonista teve impacto crucial ao longo de sua vida: "Recusava-se a admiti-la, porque não queria seguir o pai também nisso, bastava o fumo, a música e a literatura. Fechou os olhos e ouviu repetirem-se, com impressionante nitidez, os sons do violino" (KIEFER, 1995, p. 61).

Ele não entendia como a mesma mão capaz de extrair de um violino aquela melodia podia também bater numa mulher doente. Depois de idoso, ao rememorar a infância, a música estava presente em suas recordações, assim como as agruras por que passou enquanto ainda era garoto e que agora vinham-lhe perturbar o sono e surgiam como flash durante o dia, de forma explícita, a fazerlhe entender a si próprio e compreender as peças do quebra-cabeça de sua vida.

Bruno venceu o bloqueio e pôde ouvir os
gemidos, nítidos, atravessando mais de meio
século, misturando-se ao farfalhar do vento
nas folhas do eucalipto, ao mugir distante das
vacas e outros tantos ruídos do final da tarde.
Conseguiu enfim determinar o timbre exato
dos lamentos que o perseguiam em sonhos e
o levavam a gritar no meio da noite (KIEFER,
1995, p. 16).

É nítida a influência da paisagem sonora desde o início do romance, tanto que até as recordações do oleiro estavam imersas em questões permeadas pela sonoridade. Gritos, mugidos e o som produzido pelo vento nas folhas compõem a paisagem sonora que permite ao personagem rememorar seus traumas de infância. Não só a

4 Valsa: "Dança de salão mais popular do século XIX. Suas origens são obscuras, mas estão ligadas à história de outras danças de compasso ternário, a Deutsche (dança alemã) e o landler do final do séc. XVIII. A valsa cresceu em popularidade no início do século XIX, apesar das objeções levantadas por motivos médicos (a velocidade com que os dançarinos rodopiavam pelo salão) e também morais (os casais se prendiam num abraço muito estreito)" (GROVE, 1994, p, 977). 
sonoridade é parte importante das recordações, como é o principal aspecto de que o personagem se lembra. Há uma noção sonora singular, visto que se misturam sonoridades do presente da narrativa com sonoridades lembradas, ou seja, o personagem consegue lembrar os gritos de desespero e identificar, na memória, quem os emitia. Essas lembranças não são fruto do que ele viu, mas sim do que ouviu, o que revela a essência da paisagem sonora, já que ela "consiste em eventos ouvidos e não em objetos vistos" (SCHAFER, 2011, p. 24. Grifos do autor) e permite confirmar sua importância no romance. A descrição feita pelo narrador se refere a sons, e não a imagens.

Fica evidente, ainda, a relação do som com a passagem do tempo. Embora tenha se passado mais de cinquenta anos entre o fato e a lembrança do ocorrido, ainda foi possível ao personagem rememorar com clareza "O timbre exato dos lamentos" (KIEFER, 1995, p. 16); o tempo não foi capaz de apagar de sua memória a lembrança dos gritos de desespero de sua mãe ao apanhar do marido.

Tais observações permitem destacar o registro sonoro que se dá na memória, ou seja, a memória auditiva, que proporciona a recordação de sons específicos e situações que envolvam diferentes sonoridades, mesmo que estejam distantes no tempo e no espaço. A carga semântica da memória auditiva permite o desencadeamento de emoções ligadas à sonoridade, como no excerto em destaque, de onde se verifica a capacidade de influência atemporal que a paisagem sonora tem em relação aos personagens.

Outra característica do protagonista Bruno Stein, relativa à questão sonora, é que ele não gostava de televisão: "Comeu em silêncio, irritado porque a televisão continuava ligada. Sequer à mesa havia trégua” (KIEFER, 1995, p. 23). Havia pairando no ar um jogo de forças entre o velho e a máquina. O ruído produzido pelo equipamento incomodava o oleiro, que não reconhecia na televisão nada de positivo. $\mathrm{Na}$ percepção de Bruno, fora a televisão que distanciara a família: "o problema podia ser a televisão, dado que antes de sua chegada costumava reunir as netas na sala e contar intermináveis histórias. Sim, fora desbancado pelo aparelho, substituído pelas imagens coloridas" (KIEFER, 1995, p. 23). É possível perceber o lugar que cada um, Bruno e a TV, passaram a ocupar na casa. O baque nos velhos costumes gerado pela inserção da televisão foi estrategicamente pensado por Kiefer: em "Valsa para Bruno Stein eu procuro resgatar isso: mostrar de que forma a televisão influencia uma pequena comunidade rural" (KIEFER, 1991, p. 282).

Diversos elementos do texto permitem estabelecer uma relação entre a diegese e a realidade a partir da qual Charles Kiefer criou suas narrativas. O próprio autor reconhece o paralelo existente entre Pau-d'Arco e 'Três de Maio (RS). Embora se saiba que o plano ficcional e o real sejam distintos, é inegável que em alguns casos a ficção esteja associada ao real num maior grau que em outros. É o caso de Valsa para Bruno Stein, cujos elementos da realidade fazem parte do enredo. Os efeitos da presença da televisão enquanto novidade em comunidades interioranas do Rio Grande do Sul são elementos que entram em discussão na narrativa e estão pautados em fatos da realidade. Por meio de fragmentos do texto é possível identificar o canal a que tinham acesso, Rede Globo de Televisão, como em: "Depois das cenas do capítulo a ser apresentado no dia seguinte, e antes que o Jornal Nacional iniciasse, Eunice desligou o aparelho" (KIEFER, 1995, p. 96), ou ainda em "Fosse outro domingo, teria sentado diante da televisão e assistido ao Fantástico" (KIEFER, 1995, p. 148). Os programas Fantástico (produzido desde 1973) e Jornal Nacional (transmitido desde 1969) fazem parte da programação da Rede Globo de Televisão e ainda existem, sendo o primeiro transmitido nas 
noites de domingo e o segundo, em todas as outras noites da semana, com exceção do domingo. Dessa forma, é possível inferir que as novelas assistidas pelas mulheres da casa de Bruno e tão criticadas pelo personagem eram aquelas transmitidas pela Globo. Considerando que a história gira em torno do período do carnaval 5 , em 1983 (este fato fica claro porque é o ano em que a neta de Bruno, cujo aniversário seria em 23 de fevereiro, vai embora para Porto Alegre), as novelas que teriam feito parte do cotidiano das personagens seriam as que foram transmitidas nesse período. Na segunda metade de 1982 até março de 1983 eram exibidas duas novelas nessa emissora, Paraíso, às 18 horas, e Sol de Verão, às 20. Paraíso se desenvolveu em um universo rural e tratou do

[...] romance proibido entre José Eleutério (Kadu Moliterno), peão conhecido como "filho do diabo", e Maria Rita (Cristina Mullins), cujos milagres a ela atribuídos na infância a tornaram conhecida como "santinha" (BRYAN e VILLARI, 2014, p. 368).

Disso é possível depreender que até mesmo a temática da novela contemporânea à narrativa está em consonância com aspectos circundantes à história. O título da novela foi extraído da música tema de abertura, "Promessas Demais, canção pop de Moraes Moreira, Zeca Barreto e Paulo Leminski, gravada por Ney Matogrosso com marcante instrumentação mecânica" (BRYAN; VILLARI, 2014, p. 368).

Ainda ao se considerar a ligação entre a realidade e a ficção, é interessante destacar a noção de Paraíso, que é também um conceito bíblico. Assim, a atmosfera religiosa, a luta interna travada pelo oleiro (dividido entre seguir o caráter e a honestidade que pregara a vida toda, ou deixar-se perder pela tentação que a nora representava) no texto literário ficcional encontra eco no âmbito

5 Se considerarmos o calendário real, no ano de 1983 o Carnaval ocorreu no dia 15/02. da telenovela, a qual ele repudia, visto que o par romântico da dramaturgia carrega a dicotomia diabo/santa. Ademais, a trilha sonora da novela fazia parte da paisagem sonora da casa, posto que a partir da televisão o som era propagado para diferentes cômodos e, obviamente, espalhavam por lá a música da novela. No horário das vinte horas, a emissora transmitia a novela Sol de Verão,

A novela conta a história de Rachel (Irene Ravache), mãe de Clara que abre mão do casamento estável com Virgílio (Cecil Thiré) para recomeçar sua vida e viver uma nova paixão - uma trama corajosa para a época, simbolizando o momento de transição que o país vivia com o início do fim da ditadura e todas as expectativas trazidas por aquela possibilidade de liberdade (BRYAN; VILLARI, 2014, p. 369).

Não dá para deixar de perceber o fato de que a neta de Bruno Stein também deixaria o namoro infeliz e partiria para Porto Alegre, em busca de uma nova vida. A própria novela perpassa em sua trilha sonora "O otimismo juvenil naqueles últimos anos de mordaça imposta pela ditadura" (BRYAN; VILLARI, 2014, p. 369)' com músicas de Lulu Santos ("Tempos Modernos"), da banda Blitz, Guilherme Arantes, Rita Lee, Fafá de Belém, Nara Leão e Djavan, entre outros. Da mesma forma que o tema da telenovela exibida às 18 horas permite pôr em consonância o contexto da trama de Valsa para Bruno Stein, a das 20 horas também tematiza essa relação, tanto pelo viés de Verônica quanto do próprio protagonista em relação à nora, visto que ele também sofria o dilema de um casamento em que o amor não imperava, e que foi encontrado fora do casamento.

Bruno não cansava de atribuir à televisão o poder de destruição das famílias. Quando a neta resolveu ir morar em Porto Alegre, foi categórico ao dizer que “... a televisão te envenenou, despertou no teu coração o desejo e a vaidade do mundo. "Verônica, o diabo está rondando a tua vida" (KIEFER, 1995, p. 147), e quando as coisas 
tomavam algum rumo diferente do que imaginava ser o certo logo refletia: "isso é a televisão, pensou. Esses filmes de assaltos e crimes, essas novelas despudoradas" (KIEFER, 1995, p. 90). Para o protagonista, a inserção da televisão e toda a programação por ela transmitida eram responsáveis pela degradação da família, pela ruína da moral e dos bons costumes que pregara ao longo da vida, e a paisagem sonora interna da casa de Bruno estava impregnada dessa sonoridade.

Identificar as novelas e programas que as mulheres da casa assistiam e que Bruno combatia configura-se numa tentativa de também ouvir o que ele ouvia, e que, apesar de não descrito explicitamente no texto, é possível determinar a partir dos vestígios deixados pelos comentários do narrador. Bruno Stein é o maior apreciador das artes, sejam elas musicais, literárias ou visuais. Apesar de estar inserido em ambiente rústico, o oleiro é apresentado como uma pessoa que preenche seu tempo livre ouvindo música, lendo e esculpindo. Além disso, é alguém habituado a fazer reflexões sobre a vida, sobre as transformações que suas quase sete décadas de existência permitiram acompanhar. Imerso no ambiente hostil do campo, convivendo de forma distanciada com seus familiares e rodeado por trabalhadores braçais, artes como a música e a literatura estão intrinsecamente ligadas ao personagem, fazem parte da sua vida.

Provavelmente, o fato de Bruno ter acesso à arte tenha sido crucial na sua formação, e isso se revela em suas reflexões, as quais seriam improváveis em um personagem sem formação intelectual. Bruno Stein tem um nível intelectual que o difere dos demais, e encontra na arte um alento para o fim de sua vida, já que "restavam poucos prazeres na vida do oleiro Bruno Stein: o fumo, a leitura, a música e a paixão por modelar" (KIEFER, 1995, p. 13). Pode-se considerar que foi justamente a arte, através de suas diferentes manifestações, a maior responsável por tornar o oleiro diferente das pessoas com as quais convive. É possível observar, nesse aspecto, o poder humanizador da arte, já evidenciado por outros escritores e defendido por Werlang (2011), quando escreve sobre a obra de Erico Verissimo.

\begin{abstract}
Profundamente enraizada na concepção de humanismo de Erico Verissimo está a crença no poder da arte, e particularmente da música, de questionar sem palavras, de curar, de servir como um bálsamo que contenha tanto a resposta como a indagação, capazes de colocar a alma do homem a nu; poder esse que em um momento de lucidez pode levá-lo a compreender suas loucuras e a entrever a possibilidade de um futuro melhor (WERLANG, 2011, p. 294).
\end{abstract}

Tal concepção está de acordo com o que o próprio Kiefer (2002) entende a respeito da música em relação ao protagonista, quando diz que "metaforicamente, a música salva o velho patriarca, potencializa nele as pulsões de Eros" (KIEFER, 2002, p. 4). É a música que viabiliza a aproximação entre o protagonista e Valéria, e é ela também que vai ser usada como mecanismo que encobriria os sons do ato sexual. As pulsões de Eros, de acordo com a psicanálise freudiana, estão relacionadas com as pulsões de vida, opostas às pulsões de morte. $\mathrm{O}$ personagem está num limite tênue entre os dois, pois a proximidade de seu septuagésimo aniversário o leva a questionamentos que envolvem o medo da aproximação da morte ao mesmo tempo em que sua dedicação às esculturas pode ser vestígio da sua vontade de permanecer vivo. Então a música o salva no sentido de que foge à necessidade de punição pela ideia de pecado pelo envolvimento com a nora, por, finalmente, atribuir sentido à sua existência ao entregar-se aos prazeres carnais usualmente combatidos pela sociedade cristã.

Para Bruno, as diferentes representações artísticas funcionavam como uma fuga, semelhante ao destacado por Werlang (2011) ao falar do personagem Noel, de Um Lugar ao Sol, ao referir que este "busca refúgio na arte, e a música constitui-se no principal elemento de ligação com 
um mundo onírico, onde a hostilidade do mundo não encontra meios de se infiltrar" (WERLANG, 2011, p. 62). Tal hostilidade pode facilmente estar associada à falta de acesso aos bens culturais por parte das pessoas que convivem com Bruno. Assim, a exemplo de Noel, Bruno Stein também se refugia na arte, ora através das esculturas, ora através da música; era nas artes que o personagem se encontrava de verdade; ao mesmo tempo em que o afastavam de seus dilemas e problemas existenciais o mantinham ligado à vida, ainda que fosse à vida onírica, à dos sonhos e da nostalgia que ele tentava deliberadamente conservar por meio das esculturas. A arte proporciona uma atmosfera de reflorescimento de sonhos e Bruno procura refugiar-se da futilidade enclausurando-se na música.

Grande parte das reflexões de Bruno Stein ocorria especialmente em um cômodo da casa em que ele se escondia para ler seus livros, ouvir suas músicas e pensar na vida. É justamente quando o personagem está sozinho, em seu refúgio, em contato com suas músicas e suas leituras, que ele é efetivamente ele mesmo. A atmosfera criada a partir da música, da literatura, das artes em geral, faz desabrochar o Bruno que se oculta no cotidiano. A camuflagem que ele usa fica do lado de fora da porta de seu quarto. Em verdade, é possível afirmar que o refúgio não serve para sua reclusão, pois recluso ele está quando se vê acompanhado por muitas das outras pessoas que o cercam.

É em seu refúgio, tomado de paisagem musical, que Bruno se livra da âncora que o prende a uma convivência social superficial. O velho oleiro é alguém muito solitário, não há com quem conversar a respeito de arte; a música é sua interlocutora no rol de sua solidão cultural. Talvez tenha sido este o fato a aproximar nora e sogro, porque Valéria, a despeito das outras mulheres, era a única que não condenava suas preferências, e até respeitava sua reclusão. É ela que viabiliza a aproximação entre os dois, e é ela também que vai acompanhar a trajetória do protagonista até consumar seus desejos em relação à esposa do filho.

\begin{abstract}
Fechou a porta a chave, colocou um disco na vitrola, um pesado e grosso disco da RCA Victor, e esparramou-se no sofá. Os suaves acordes do terceiro movimento da Sinfonia ${ }^{6}$ $\mathrm{n}^{\mathrm{o}}$ 40, em Sol Menor, de Mozart ${ }^{7}$, encheram a peça. Diminuiu o volume, antes que viessem chamar-lhe a atenção. Deixou que a música entrasse não apenas pelos ouvidos, mas também pelos poros. Mozart, sopro de Deus, prova maior da divindade revelada no homem (KIEFER, 1995, p. 88).
\end{abstract}

A cena acima permite entender a música como um dos mais altos graus da capacidade criativa e talentosa do ser humano, cujos dons se revelam através da criação artística, conceito que se aproxima do que Schafer (2011) diz em relação à música, pois

[...] a paisagem sonora é demasiado complexa
para ser reproduzida pela fala humana. Assim,
somente na música é que o homem encontra
verdadeira harmonia dos mundos interior e
exterior. Será também na música que ele criará
os seus mais perfeitos modelos da paisagem
sonora ideal da imaginação (SCHAFER, 2011,
p. 70).

Harmonia essa a que o protagonista tem acesso especialmente no refúgio, pois os elementos sônicos que fazem parte do cotidiano de Bruno criam um mundo sonoro específico e particular, em que a música se destaca em detrimento dos demais sons, formando a essência da paisagem sonora individual do personagem; dentro do mundo sonoro da propriedade, há um recorte sônico

6 Sinfonia é o "termo usado a partir do Renascimento para designar vários tipos de peças (geralmente instrumentais)". Em torno de 1700, usava-se indistintamente "sonata" e "sinfonia" para peças instrumentais. A partir do século XVIII, sinfonia designa uma peça instrumental para orquestra, em vários movimentos distintos. No decorrer daquele século torna-se a maior e mais importante forma instrumental da música desde então (GROVE, 1994, p, 868).

7 Wolfgang Amadeus Mozart (1756 - 1791): compositor austríaco, cujo talento musical foi demonstrado muito cedo, compondo já aos cinco anos. Incrivelmente talentoso, retratou emoções heroicas e dramáticas em sua vasta obra, a qual o faz figurar entre os mais importantes compositores da história da música (GROVE, 1994, p, 626). 
particular em relação ao personagem Bruno, que é repleto de música.

\section{É ímpar a paisagem sonora no fragmento do} texto ficcional em destaque, pois naquele refúgio o espaço estava todo ocupado pela música, é como se ela ganhasse corpo; cria-se uma imagem semelhante a de um balão cheio de ar, na qual o balão são as paredes do quarto e a música é o ar que preenche o espaço. De acordo com Schafer (2011), a própria concepção da sinfonia naturalmente foi pensada para ser executada em ambiente fechado, quando o avanço tecnológico fez com que o ambiente das ruas fosse mais carregado sonoramente, inviabilizando a execução musical.

\begin{abstract}
A música absoluta é desvinculada do ambiente externo e suas mais altas formas (a sonata, o quarteto, a sinfonia) são concebidas para serem executadas a portas fechadas. $\mathrm{Na}$ verdade, elas parecem ganhar importância na razão direta do desencanto do homem com a paisagem sonora externa. A música muda-se para dentro das salas de concerto quando já não podem ser ouvidas efetivamente do lado de fora. Ali, por detrás das paredes acolchoadas, a audição concentrada torna-se possível. Isso equivale a dizer que o quarteto de cordas e o pandemônio urbano são historicamente contemporâneos (SCHAFER, 2011, p. 151).
\end{abstract}

Em Valsa para Bruno Stein, o ambiente externo ao refúgio de Bruno era contaminado por sonoridades que o incomodavam, especialmente pela televisão, que por extensão representa as transformações tecnológicas pelas quais a sociedade gaúcha da época passou. No contexto da casa, o local mais apropriado para a apreciação de uma sinfonia era justamente o quarto, embora a música não fosse executada ao vivo, mas reproduzida na vitrola que Bruno retirou da sala assim que a televisão chegou, e da qual ninguém deu falta. A partir do quarto, o som se propagava pela casa, e era ouvido por Valéria.

Recostada contra a guarda da cama Valéria ouviu quando a televisão foi desligada. A descarga do vaso sanitário repetiu-se várias vezes, antes das filhas se recolherem. Podia ouvi-las comentando sobre a novela. $\mathrm{Na}$ cozinha, Olga lavava talheres, pratos e panelas. Algum tempo depois que a sogra terminou a limpeza e foi dormir conseguiu ouvir a suave música no escritório. Deixou-se embalar, como se as cordas a ninassem. Imaginou o sogro, cabeça enterrada no peito, as mãos cruzadas no colo, entregando-se à música (KIEFER, 1995, p. 97).

A paisagem sonora dessa sequência permite identificar quatro cenas distintas que acontecem concomitantemente dentro da casa. A partir da narração do narrador em terceira pessoa e através dos ouvidos de Valéria (cena um) é possível definir o que acontece em cada cômodo, com cada personagem. Ao mesmo tempo em que a televisão foi desligada na sala (cena dois), a louça estava sendo lavada na cozinha (cena três) e música era ouvida no refúgio, antigo escritório em que Bruno se escondia de todos (cena quatro). A sonoridade demarca mais do que apenas o que acontecia com cada um dos membros da família, pois revela também o lugar social de cada um. Bruno e Valéria (de uma geração posterior à de Bruno), estão imersos em seu mundo particular, um ouvindo música e o outro ruminando seus pensamentos carregados de desejos carnais. Isso evidencia um caráter particular da paisagem sonora, visto que "a audição é um modo de tocar a distância, e a intimidade do primeiro sentido funde-se à sociabilidade cada vez que as pessoas se reúnem para ouvir algo especial" (SCHAFER, 2011, p. 29). Sogro e nora não se reúnem num mesmo cômodo para ouvir o mesmo som, mas estão, de alguma forma, ligados pela mesma música.

Quando os outros ruídos cessaram, Valéria pôde deleitar-se também com o que o sogro ouvia. O elo entre eles nesse momento passa a ser a música, porque mesmo estando em lugares diferentes dentro da mesma casa, os dois estão entregues à mesma sonoridade.

No entanto, o papel atribuído à música em Valsa para Bruno Stein vai muito além de um elo sônico entre apaixonados, já que Valéria planejara 
se aproveitar da sonoridade musical para encobrir os vestígios sonoros de sua entrega sexual ao sogro. "Apurou o ouvido: a casa dormia. Olga tinha sono pesado, o quarto das filhas ficava longe do escritório, a música abafaria os gemidos" (KIEFER, 1995, p. 98). A música seria aliada, abafando os ruídos do sexo.

Na cena que se segue após Valéria acompanhar de ouvido o que estava acontecendo no restante da casa e ao constatar que não seria ouvida caso fosse visitar o sogro em seu refúgio decide partir rumo a seu intento de entregar-se a ele. "Deslizou pelo quarto, descalça, atravessou a cozinha com passo de gata, largando a sola do pé com suavidade sobre o assoalho, alcançou o escritório com a respiração ofegante" (KIEFER, 1995, p. 98). Aqui se identifica a singularidade do silêncio, do não produzir ruído, das artimanhas da mulher para não ser pega em flagrante, e para isso desloca-se com cuidado pela casa que, por ser de assoalho de madeira, poderia produzir rangidos ao menor descuido, denunciando sua presença, especialmente se mais alguém na casa estivesse apurando os ouvidos para ouvir os sons produzidos em cada cômodo.

É incontestável que a música mexe com a mulher, já que influencia no pulsar do sangue em suas veias. Logo que chega perto do refúgio do sogro ela se sente insegura, e nesta parte a paisagem sonora adquire a corporeidade dos demais elementos que constroem a cena, pois "os acordes da flauta, e a expectativa, a indecisão entre recuar e avançar para os braços de Bruno ou para a vergonha, aumentavam o pulsar de suas veias" (KIEFER, 1995, p. 98), o que remete à ideia de algo que quer ir, mas se sente preso por algo, de forma semelhante a como são produzidos os acordes da flauta, através dos dedos que tapam ou destapam os orifícios do tubo oco de onde sai o som.

\section{A MÚSICA NOS SONHOS DO PROTAGONISTA}

Além de fazer parte da memória auditiva do personagem e de ser propulsora de algumas ações no texto, a música também tinha lugar nos pesadelos de Bruno. Em dado momento ele sonha que ouve uma valsa tocada pelo pai, em homenagem a ele, e na sequência aparece a mãe, toda deformada, provavelmente em referência às feridas físicas e emocionais que carregara e que foram presenciadas pelo garoto na infância. Ele pressupõe que o sonho lhe veio como um castigo pelos sentimentos imorais que vinha nutrindo e pela forma austera como tratava as pessoas ao seu redor. Nesse contexto onírico,

\begin{abstract}
Ouviu-se então um acorde de violino, provindo de um canto da sala. Da penumbra surgiu um homem esquálido, cambaleante, agitando freneticamente $\mathrm{O}$ arco. $\mathrm{O}$ som subia, as notas tornavam-se mais e mais agudas. Súbito, o solo cessou. Não, o homem disse. Bruno odeia valsas e ouvirá uma em sua homenagem. Pasmo, lívido, suspenso entre o desespero e a loucura, reconheceu-o. Uma valsa para bruno Stein! Exclamou o pai, curvando-se numa prolongada mesura. Ao tempo em que a valsa principiava, surgiu na sala, marcando o compasso ternário com a bengala, a mãe, trajada de preto, a face descarnada, sem os olhos nas órbitas, e o convidou para dançar (KIEFER, 1995, p. 104).
\end{abstract}

A presença da música torna o sonho/ julgamento um verdadeiro pesadelo, pois Bruno odiava valsas e uma delas passou a ser tocada em sua homenagem. O pai, responsável pelo trauma que acompanhou Bruno por toda vida, volta à sua memória para aplicar-lhe uma espécie de pena depois do julgamento. E isso se dá através da música. Essa atmosfera gera uma mistura de sensações no protagonista, cujo problema advém da "lembrança da nora em trajes íntimos, o som do violino do pai e a imagem repugnante da mãe" 
(KIEFER, 1995, p. 105). Isto é, lembranças sônicas e de imagens vistas e sonhadas compõe o tormento de Bruno.

Ocorre que mais adiante, já no desfecho da trama, o personagem é colocado diante de uma situação muito semelhante à do sonho, quando, após praticar o ato sexual com a nora percebe que

De repente atravessou a noite um sonido agudo, de compassos marcados. Reconheceu a valsa: a mesma que o pai arrancava do violino em seus intermináveis ensaios (...) - Uma valsa para Bruno Stein! - exclamou uma voz arrastada (KIEFER, 1995, p. 173).

O som da valsa desperta de imediato as recordações do sonho, cujas imagens voltam instantaneamente à memória, pois "Bruno recordou-se do pesadelo: a prolongada mesura do pai, o arco agitado freneticamente, o som furandolhe os tímpanos, a mãe, sem os olhos nas órbitas, convidando-o para dançar" (KIEFER, 1995, p. 174). Ou seja, mais uma vez a música adquire aura de coisa viva, posto que desperta no protagonista um estado anímico incomum para o momento. A figura de linguagem utilizada no excerto remete não ao volume do som da valsa, mas ao efeito que aquele tipo de música era capaz de desencadear em Bruno. Tanto a recordação sonora da valsa quanto aquela assoviada no presente da narrativa não teriam capacidade para furar os tímpanos de quem quer que fosse, porém, as recordações que evocavam tinham o poder de acionar o caos na mente do oleiro. A paisagem sonora, neste caso, é responsável pelo estado anímico do personagem.

$\mathrm{Na}$ sequência, "Arno Wolf, retornando o assovio da valsa, cambaleou rumo à olaria" (KIEFER, 1995, p. 100), a qual ardia em chamas. Arno estava bêbado enquanto assoviava a valsa na propriedade de Bruno e isso remete diretamente ao pai do personagem, pois era nos momentos de bebedeira que fazia as atrocidades contra a mulher, das quais o protagonista lembra no início da narrativa. A associação feita através da bebida entre Wolf e o pai de Bruno é significativa à medida que ele não impede que o bêbado vá à olaria, mesmo que este não disponha no momento de suas faculdades mentais, devido à ingestão de álcool.

Bruno ouve o bêbado gritar "- Uma valsa para Bruno Stein! E depois o assovio e o arrastar de alpargatas pelo chão de terra" (KIEFER, 1995, p. 172). Ou seja, misturados aos gritos estão os assovios, maneira encontrada pelo personagem para executar a canção. A singularidade das significações desse tipo de representação sonora é destacada por Werlang (2011) ao afirmar que "muito além da alegria, o assobio é uma manifestação inequívoca daquilo que poderia ser melhor. $\mathrm{Na}$ falta de qualquer possibilidade de realizar seus sonhos, a melodia assobiada é a expressão musical da esperança" (WERLANG, 2011, 361). O leitor talvez pudesse inclinar-se a pensar que a valsa assoviada por Arno viesse a soar em seus ouvidos como um castigo, como a acusação de todos os seus defeitos, os mesmos que ele costumava apontar nos outros e que a partir daquele dia poderia reconhecer em si, embora com algumas diferenças, pois enquanto o pai batia em sua mãe doente ele traía o filho em sua própria casa, relacionando-se sexualmente com a nora. Porém, considerando que a valsa é símbolo de um rito de passagem, ela pode ter sido apresentada como uma espécie de comemoração. Uma valsa assoviada no final da narrativa talvez equivalha à esperança de uma nova vida, de uma maneira inaugural para ele de encarar sua existência, no auge de seus setenta anos. Talvez ela tenha marcado a travessia, o rito de estreia a essa nova vida. Talvez ela seja a homenagem pela passagem de Bruno de uma vida reta, honrada, religiosa, temente a Deus, para, finalmente, entregar-se àquilo a que ele havia sido concebido para ser.

Bruno, então, retorna para o interior da casa, onde a televisão estava ligada, transmitindo o desfile de carnaval. Não é fortuito o período do 
ano escolhido pelo autor para a narrativa, pois essa época perpassa, pelo viés religioso, a questão da tentação e do pecado, expresso também na valsa que Arno Wolf assovia (Mephisto, de Liszt). No texto são apresentadas diferentes visões a respeito da festa. Bruno "jamais permitira que as netas frequentassem os bailes de carnaval" (KIEFER, 1995 , p. 154) porque, segundo ele, "eram dias do demônio, dias em que ele andava às soltas" (KIEFER, 1995, p. 154); as netas, porém, sentiam vontade de participar dos festejos de carnaval. Para os funcionários da olaria, "nesses quatro dias de folia as pessoas deixam de ser hipócritas. São quatro dias em que a verdadeira natureza de cada um vem à tona e a ideia do pecado desaparece da terra" (KIEFER, 1995, p. 165).

Esse comentário está em conformidade com os traços particulares de Bruno, pois o protagonista passa toda a narrativa dividido entre pecados e virtudes, usando a palavra de Deus e criticando quem não a seguia, mas no fundo o que ele tinha era medo de sucumbir ao pecado, que é o que acontece. Considerando que ele cedeu aos desejos carnais e acabou se envolvendo sexualmente com a nora exatamente na época do carnaval, época em que, de acordo com a visão de Erandi, as pessoas revelam sua verdadeira natureza, fica subentendido que ali ele deixou de ser hipócrita, porque abriu mão do medo do pecado e resolveu fazer o que tinha vontade, desconsiderando os preceitos bíblicos que pregara durante toda sua vida.

No entanto, essa percepção de si mesmo que o personagem só conseguiu aceitar no fim da narrativa já tinha sido antecipada pela nora, quando refletia sobre o sogro. "Sabia que por trás da máscara de pureza, sob os olhos embotados e provérbios bíblicos, ardia o instinto; sob as cinzas ainda havia brasas e bastaria um sopro para reavivá-las" (KIEFER, 1995, p. 97). Tal sopro veio e reacendeu a vida do homem septuagenário, que a partir dali não mais se importou com o suposto poder da televisão de destruição da moral e dos bons costumes, pois na cena final posta-se diante do aparelho eletrônico a fim de ver o desfile das escolas de samba. Dessa forma, "sem o saber, Bruno Stein acabara de acrescentar mais um prazer à sua já longa e atribulada existência" (KIEFER, 1995, p. 175). Consoante com a opinião de Valéria a respeito do sogro, está a do próprio autor em relação ao seu protagonista, pois

\begin{abstract}
[d]esde o princípio, eu sabia que o próprio nome do personagem já carregava o centro do conflito da trama: a dicotomia entre pecado e virtude, o fim de algo e o começo de outra coisa, Bruno, bruma, leveza, e Stein, pedra, na língua alemã. Escrever o romance não foi mais do que ir atrás das verdades que já estavam enrodilhadas no vir-a-ser da frase inicial (KIEFER, 2002, p. 41. Grifos do autor).
\end{abstract}

Bruma é uma palavra que pode facilmente estar associada ao personagem Bruno, pois ele era realmente sensível quando ouvia boas músicas e lia bons livros, da mesma forma que era perspicaz quando esculpia com tanta sutileza de detalhes os familiares. Mas também era pedra quando se fazia enérgico com os funcionários, quando era intransigente com a família, quando se revelava um forte trabalhador braçal. Era bruma quando amava, era pedra quando tentava negar o que sentia. Era pedra quando detestava televisão, carnaval, ou qualquer mudança que viesse com o tempo, mas era bruma quando se deixava, finalmente, seduzir por aquilo que sempre condenou. Era pedra quando ouvia valsas. Mas a pedra virou bruma quando percebeu que a vida não precisava ficar presa no passado, e que mesmo ao completar setenta anos ele ainda poderia viver muita coisa. A vida não estava no fim, porque a nova vida estava recém no começo.

\section{CONSIDERAÇÕES}

Quando lemos, nosso pensamento se apropria de imagens, sabores e sons. Essa 
percepção permite estabelecer uma transmutação de sentido ao se fazer uma análise como a que foi desenvolvida aqui, como uma experiência de abrir uma janela diferente para entender a literatura, para ouvir literatura, já que o propósito da análise da paisagem sonora é também uma tentativa de ouvir aquilo que muitas vezes não está claro na palavra.

Há uma expansão no modo de criar significações, pois a percepção da paisagem sonora transmuta a maneira comum de produção de sentidos ao alargar a possibilidade de verossimilhança, que em última análise é uma maneira de produzir sentidos para a vida. Paisagens sonoras ampliam o terreno da verossimilhança, pois a partir dela se ouve muito mais do que apenas sons, se ouve contextos, subjetividades, dramas humanos permeados pela sonoridade.

Em Valsa para Bruno Stein a paisagem sonora que acompanha o personagem na trajetória em que ele tenta encontrar a si mesmo é repleta de música. Pode-se dizer que, para Bruno, o tempo é musical; a ultrapassagem, a inauguração de uma nova vida para o personagem se dá ao som de música.

Assim como "antes da era da escrita, na época dos profetas e épicos, o sentido da audição era mais vital que o da visão. A palavra de Deus, a história das tribos e todas as outras informações importantes eram ouvidas, e não vistas" (KIEFER, 2011, p. 28), em Valsa para Bruno Stein, paisagem sonora (que é recebida pelos personagens por meio da audição) adquire uma profunda significação no enredo, tendo em vista as diferentes reações, especialmente do protagonista, à sonoridade que o circunda.

\section{REFERÊNCIAS}

BRYAN, Guilherme; VILLARI, Vincent. Teletema: volume I - 1964 a 1989. A História da Música Popular através da Teledramaturgia Brasileira. São Paulo: Dash, 2014.
DEBORTOLLI, Viviane Aparecida Pandolfo; WERLANG, Gérson Luís. Bruno Stein sob a Perspectiva Teórica estruturalista. In: Revell Revista de Estudos Literários da UEMS, n. 22, v. 2, p. 506-526, 2019.

DEBORTOLLI, Viviane Aparecida Pandolfo; WERLANG, Gérson Luís. A paisagem sonora como elemento constitutivo do conto "O Poncho", de Charles Kiefer. In: Eixo Roda, Belo Horizonte, v. 29, n. 1, p. 255-274, 2020.

GROVE. Dicionário Grove de música: edição concisa. Editado por Stanley Sadie. Rio de Janeiro. Zahar, 1994.

KIEFER, Charles. A última trincheira: arte, cultura e identidade nacional. Porto Alegre: Artes e ofícios, 2002.

. Os Problemas do Meio Rural na Literatura Gaúcha. In: RÖSING, Tânia (Org.). Jornadas literárias: $\mathrm{O}$ Prazer do Diálogo entre Autores e Leitores. Passo Fundo: UPF, 1991. p. 281.

Valsa para Bruno Stein. 5. ed. Porto Alegre: Mercado Aberto (Série Novo Romance), 1995.

SCHAFER, R. Murray. A afinação do mundo. 2. ed. São Paulo: UNESP, 2011.

WERLANG, Gérson Luís. A música na obra de Erico Verissimo: Polifonia, Humanismo e Crítica Social. Passo Fundo: Méritos, 2011. 